\title{
FACTOR ANALYSIS OF PROFIT IN THE PRODUCTION OF VEGETABLE OILS AND ANIMAL FAT IN STARA ZAGORA
}

\author{
Iv. Georgiev, O. Milev* \\ Department "Economics”, Faculty of Economics, Trakia University, Stara Zagora, Bulgaria
}

\begin{abstract}
In analyzing the two approaches - "total revenue - total cost" and the so-called marginal approach aims to determine the level of production in which profit is maximized. Approach "marginal revenue - marginal cost" is more accurate, where the focus is cost recovery.

The results are based on an empirical study of 2012 levels of production of one of the leading companies in the sub-sector activities, as are certain critical points in the maximization of profit.

In methodological terms because of the specificity of the analysis at maximization of profit that totals for revenue and expenditure of the overall activity may not be sufficient to achieve the objective data on levels of production are focused on specific proceedings, namely the production of plant and animal oils and fats of "C" producer within one calendar year.

The conclusion is related to the evaluation of the results of the study and display of summary conclusions and recommendations.
\end{abstract}

Key words: factor analysis, profit, and cumulative marginal approach, food industry

\section{INTRODUCTION}

The economic relationship between production costs and revenue yields the following critical points, namely [3]:

- profitability threshold;

- maximum profit;

- profit margin.

Maximum profit is attained when the revenue from selling the last unit of output equals the costs made for its production, this is the socalled equality of marginal costs and marginal revenue [2].

The interrelationships between the value of output and total cost demonstrate that revenue is equal to all production costs. if the costs made by the producer attain this point, the revenue would be lower than costs and loss will be incurred. This is the so-called "profitability threshold".

Maximum profit. The zone of the profit begins from the profitability threshold and is economically explained by decline of the

\footnotetext{
*Correspondence to: Oleg Milev PhD , Bulgaria, Stara Zagora, Trakia University, Faculty of Economics, Department of Economics, Student campus, +35942699400 ,

E-mail: georgiev@uni-sz.bg
}

average total cost line under the price level, and total revenue exceeds the total cost. The profit zone is limited by the intercept of total cost and total output value, or the intercept of average total costs and the price. The maximum profit is mathematically calculated as the greatest difference between total revenue and total cost.

Profit margin. The zone after the profit is characterized with repeated preponderance of average total cost over the output price leading to formation of the so-called "second economic loss zone" [1].

In the studied case, when the market price of a given product from the food industry equals the average variable costs, the company could reinstate only the variable costs but not the fixed costs.

\section{PROFIT ANALYSIS}

When determining the amounts of vegetable oils and animal fat that have to be produced, the sum added to the revenue and cost by each additional unit of output should be compared, i.e. to compare the marginal revenue and the marginal cost. Considering that the marginal revenue from the production of one additional 
output unit at each point of the production curve is defined as the ratio of total revenue increase rate to the output increase rate, it follows that the marginal revenue at each level of vegetable oils and animal fat production is equal to the price of the product, i.e. 1.8 thousand BGN per 1 ton (Table 1).

Table 1. Profit maximization of vegetable oils and animal fat production in 2012.

\begin{tabular}{|c|c|c|c|c|c|c|}
\hline $\begin{array}{c}\text { Total } \\
\text { product } \\
\text { TP } \\
\text { (tone) }\end{array}$ & $\begin{array}{c}\text { Price } \\
\text { P } \\
\text { (thousand } \\
\text { BGN/tone) }\end{array}$ & $\begin{array}{l}\text { Total } \\
\text { revenue } \\
\text { TR } \\
\text { (thousand } \\
\text { BGN) }\end{array}$ & $\begin{array}{c}\text { Total cost } \\
\text { TC } \\
\text { (thousand } \\
\text { BGN) }\end{array}$ & $\begin{array}{c}\text { Profit / } \\
\text { Loss } \\
\text { (thousand } \\
\text { BGN) }\end{array}$ & $\begin{array}{c}\text { Marginal } \\
\text { cost } \\
\text { MC } \\
\text { (thousand } \\
\text { BGN/tone) }\end{array}$ & $\begin{array}{c}\text { Marginal } \\
\text { revenue } \\
\text { MR } \\
\text { (thousand } \\
\text { BGN/tone) }\end{array}$ \\
\hline 3820 & 1,8 & 6876 & 4660 & 2216 & \multirow{3}{*}{$\begin{array}{l}0,92 \\
0,81\end{array}$} & 1,8 \\
\hline 3940 & 1,8 & 7092 & 4770 & & & 1,8 \\
\hline 4160 & 1,8 & 7488 & 4950 & & & 1,8 \\
\hline 4320 & 1,8 & 7776 & 5123 & & \multirow{3}{*}{$\begin{array}{l}1,08 \\
1,29 \\
1,48 \\
1,81\end{array}$} & 1,8 \\
\hline 4440 & 1,8 & 7992 & 5278 & & & 1,8 \\
\hline 4560 & 1,8 & 8208 & 5456 & $2752<$ & & 1,8 \\
\hline 4720 & 1,8 & 8496 & 5746 & $3020<$ & \multirow{2}{*}{$\begin{array}{l}1,01 \\
1,92 \\
2,11\end{array}$} & 1,8 \\
\hline 4830 & 1,8 & 8694 & 5957 & $2737<$ & & 1,8 \\
\hline 4950 & 1,8 & 8910 & 6210 & $2700<$ & \multirow{3}{*}{$\begin{array}{l}2,27 \\
2,32\end{array}$} & 1,8 \\
\hline 5050 & 1,8 & 9090 & 6437 & $2653<$ & & 1,8 \\
\hline 5170 & 1,8 & 9306 & 6715 & $2591-$ & & 1,8 \\
\hline
\end{tabular}

The analysis of the relationship between the output monetary value and total cost reveals that at a level close to 5600 thousand BGN, the production revenue is equal to the costs. This level could be assumed as the "profitability threshold" of the production of vegetable oils and animal fat. On the right of this point lies the zone of the profit, where the ratios between marginal revenue and marginal cost are of interest.

Taking into consideration the functional relationship between marginal revenue and marginal cost, it could be anticipated that the maximum profit will be in the point at which values of both parameters are equal or at least, as close as possible. The analysis of results from Table 1 at different production levels makes clear that the maximum profit (in grey) is attained at a production level of 4720 tones. The total revenue at this production level is 8496 thousand BGN, and the adequate total cost - 5746 thousand BGN. At this point from the production curve, the marginal cost /1.81/ is as close as possible to the marginal revenue (price) -1.8 thousand $\mathrm{BGN}$ tone and respectively, the profit is maximum /3020 thousand BGN/.

Table 2. Determination of the critical points of profit maximization of vegetable oils and animal fat production in 2012.

\begin{tabular}{|c|c|c|c|c|c|c|c|}
\hline $\begin{array}{c}\text { Total } \\
\text { product } \\
\text { TP } \\
\text { (tone) }\end{array}$ & $\begin{array}{c}\text { Total cost } \\
\text { TC } \\
\text { (thousand } \\
\text { BGN) }\end{array}$ & $\begin{array}{c}\text { Total } \\
\text { revenue } \\
\text { TR } \\
\text { (thousand } \\
\text { BGN) }\end{array}$ & $\begin{array}{l}\text { Profit / } \\
\text { Loss } \\
\text { (thousand } \\
\text { BGN) }\end{array}$ & $\begin{array}{c}\text { Marginal } \\
\text { cost } \\
\text { MC } \\
\text { (thousand } \\
\text { BGN/tone) }\end{array}$ & $\begin{array}{c}\text { Average } \\
\text { variable } \\
\text { cost } \\
\text { AVC } \\
\text { (thousand } \\
\text { BGN/tone) }\end{array}$ & $\begin{array}{c}\text { Average } \\
\text { total cost } \\
\text { ATC } \\
\text { (thousand } \\
\text { BGN/tone) }\end{array}$ & $\begin{array}{l}\text { Profit per } \\
\text { unit } \\
\text { production } \\
\text { (thousand } \\
\text { BGN/tone) }\end{array}$ \\
\hline 3820 & 4660 & 6876 & 2216 & \multirow{11}{*}{$\begin{array}{l}0,92 \\
0,81 \\
1,08 \\
1,29 \\
1,48 \\
1,81 \\
1,92 \\
2,11 \\
2,27 \\
2,32\end{array}$} & 0,85 & 1,22 & 0,58 \\
\hline 3940 & 4770 & 7092 & 2322 & & 0,84 & 1,21 & 0,59 \\
\hline 4160 & 4950 & 7488 & 2538 & & 0,83 & 1,19 & 0,61 \\
\hline 4320 & 5123 & 7776 & 2653 & & 0,83 & 1,18 & 0,61 \\
\hline 4440 & 5278 & 7992 & 2714 & & 0,83 & 1,18 & 0,61 \\
\hline 4560 & 5456 & 8208 & 2752 & & 0,84 & 1,20 & 0,60 \\
\hline 4720 & 5746 & 8496 & 3020 & & 0,81 & 1,17 & 0,64 \\
\hline 4830 & 5957 & 8694 & 2737 & & 0,86 & 1,23 & 0,57 \\
\hline 4950 & 6210 & 8910 & 2700 & & 0,88 & 1,25 & 0,55 \\
\hline 5050 & 6437 & 9090 & 2653 & & 0,89 & 1,27 & 0,53 \\
\hline 5170 & 6715 & 9306 & 2591 & & 0,91 & 1,30 & 0,50 \\
\hline
\end{tabular}




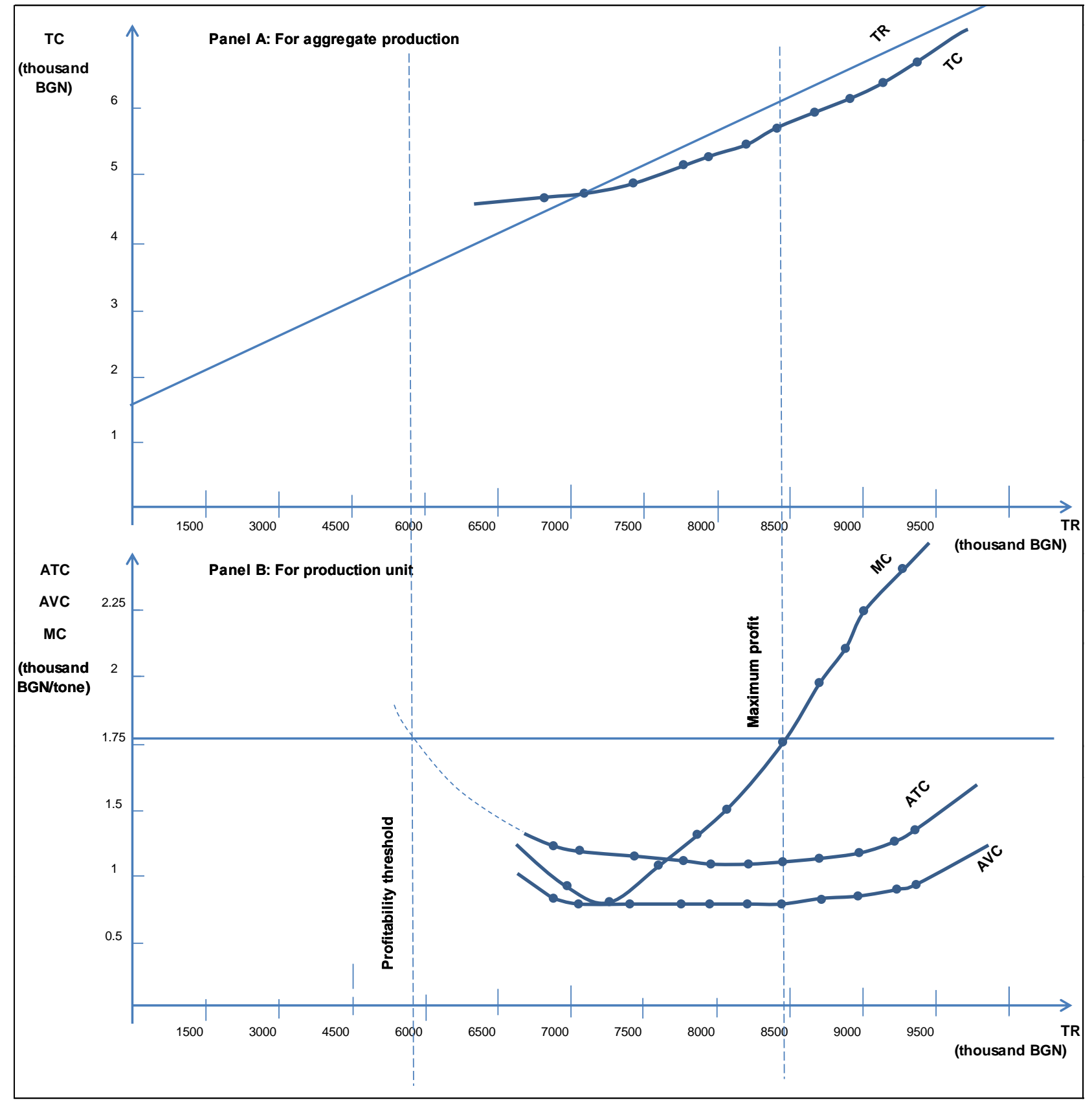

Figure 1. Profit maximization of vegetable oils and animal fat production in 2012.

It is obvious that from the point of view of the economic interest of the company (maximum profitability) the latter should be focused on maintenance of the production of vegetable oils and animal fat at an output level close to 4720 tones. In this point, the combination of total revenue and total cost results in the best recovery of cost. The level of vegetable oils and animal fat production where maximum profitability is observed could be either higher or lower if the price of the production from one hand, or the price of production factors (raw materials, fuel, energy cost, wages etc.) on the other are altered. In this case, the methodical approach is the leading one and it allows determining the optimum level of vegetable oils and animal fat production with maximum profitability for every specific situation (dynamics of production, product prices and costs). What is important, is to understand and analyze the economic relationships from this result (Table 2).

The curve depicts the decline in average total cost line below the marginal revenue (price) line. The greatest difference occurs at the intercept of marginal cost and marginal revenue (at production level of 4720 tones) and the respective revenue of 8496 thousand BGN (Table 1), when the profitability of vegetable oils and animal fat production attains its maximum of 3020 thousand BGN. The results about the cost and revenue of one unit output (Table 2) show that at the specified production 
level (maximum profitability), the average variable cost $/ \mathrm{AVC} /$ and average total cost /ATC/ are the lowest and attain 0.81 thousand BGN /tone and 1.17 thousand BGN/ tone respectively - thus, the profit from 1 tone vegetable oils and animal fat produce would be 0.64 thousand BGN.

The graphic interpretation of the relationship shown on Figure 1 demonstrates that the profit margin is attained at the level where revenue is close to 10000 thousand BGN corresponding to approximately 6000 tones of produce, when the average total costs equal again the product price (marginal revenue). After that, the production level would correspond to higher average total costs vs marginal revenue (1.8 thousand $\mathrm{BGN} /$ tone) i.e. to the so-called „second economic loss zone".

The analysis shows clearly that the vegetable oils and animal fat production at a level below 3000 tones and above 6000 tones has no economic sense, because each additional output unit would generate more additional costs and therefore, economic losses from the production.

The pessimistic variant is when the market price of produce resulting from changed market offer and demand begins to drop, i.e. the marginal revenue decreases below 1.8 thousand BGN/tone and attains the lowest level of average variable costs ( 0.81 thousand $\mathrm{BGN} /$ tone). In this case when only the average variable costs are covered by the price, the producers could keep going on only in the short run in the expectation of another rise in vegetable oils and animal fat prices. The production at prices lower than the total variable costs incurs losses for the production and thus, the lowest average variable costs could be regarded as "production threshold".

\section{CONCLUSION}

The results from the analysis allowed affirming that the production of vegetable oils and animal fat should be closely monitored with respect to the critical points "profitability threshold", "maximum profit" and "profit margin" in order to obtain good financial outcome.

The analysis of the possibility for profit maximization of vegetable oils and animal fat production (on the basis of specific production conditions) gave a methodical approach whose critical points profitability threshold (at a level of production 3000 tones), maximum profit (at a level of production 4720 tones) and profit margin (at a level of production 6000 tones) and production threshold yielded in economically efficient and sound solutions from the point of view of profit maximization. The utilized factor analysis and the regression coefficients could be calculated for the entire branch and sub-branch, as well as for each individual food production company.

\section{REFERENCES}

1. Георгиев, Ив., Аграрна икономика, Кота, Стара Загора, 2007.

2. Cramer, G., Cl. Jensen, Agricultural Economics and Agribusiness, John Willey \& Sons, New York, 1994.

3. Милев, О., Рентабилност на Хранителната индустрия в област Стара Загора, Дисертация, Стара Загора, 2014. 